\title{
Student-Centered Learning and the Climate Crisis
}

\author{
George M Jacobs ${ }^{1}$ \\ \{george.jacobs@gmail.com\} \\ ${ }^{1}$ Kampung Senang Charity and Education Foundation \\ Singapore
}

\begin{abstract}
This paper has three parts. The first part briefly reviews the meaning of student-centered learning. The second part looks at some of the causes of the current climate crisis. The third and longest part of the part offers suggestions as to what education institutions, teachers, and students can do to address the climate crisis.
\end{abstract}

\section{Part 1 - Student-Centered Learning}

Student-centered learning and teacher-centered learning and are best seen as a continuum, not as an either/or dichotomy. Table 1 highlights some of the characteristics on which student-centered and teacher-centered differ.

Table 1 - Characteristics Along a Continuum on Which Student-Centered Learning and Teacher-Centered Learning Differ

\begin{tabular}{|l|l|}
\hline Student-Centered Learning & Teacher-Centered Learning \\
\hline Teachers talk less & Teachers talk more \\
\hline $\begin{array}{l}\text { Students makes some decisions about what } \\
\text { and how to study }\end{array}$ & $\begin{array}{l}\text { Teachers make all decisions about what and } \\
\text { how to study }\end{array}$ \\
\hline Students regularly talk to peers & Students seldom talk to peers \\
\hline Students do some assessment & Teachers do all assessment \\
\hline Teachers sometimes also learn & Teachers teach; they do not learn \\
\hline Learning focuses on real life & $\begin{array}{l}\text { Learning focuses on what is in textbooks and } \\
\text { other materials }\end{array}$ \\
\hline
\end{tabular}

Many methodologies fit under the student-centered learning umbrella. These methodologies include cooperative learning [1], multiple intelligences [2], extensive reading (Extensive Reading Foundation, n.d.), problem-based learning [3], positive education [4], higher-order thinking [5-6] and self-directed learning [7]. These student-centered methodologies overlap and can complement each other.

Student-centered learning fits with an overall paradigm shift in society toward more power for the people who previously were at or near the bottom of power hierarchies. For example, in the past two hundred years, females have gained more power and education. Slavery has been greatly reduced. Minorities have more rights, as do blue-collar workers. This trend toward equality is also reflected in education, with more power for students, as well as more 
power for teachers in the overall running of educational institutions. Part 3 of this paper examines how this power might be used to address the climate crisis, but first Part 2 looks at causes of the climate crisis.

\section{Part 2 - Causes of the Climate Crisis}

The climate crisis is by no means a new concept. It refers to the growing accumulation of greenhouse gases in the Earth's atmosphere which can cause a range of difficulties including rising sea levels, more extreme weather events (such as droughts, storms, and floods), higher temperatures, and worsening harvests. Some scientists have for decades been warning about the climate crisis. However, even now, some scientists, governments, companies, and individuals continue to ignore or only pay lip service these dangers.

Many forces have caused the climate crisis, with human actions accounting for the majority of them. In recognition of human impact, some scientists call our current geologic age the Anthropocene [8]. The previous geologic age was the Holocene, which began about 11,000 years ago. The prefix anthro means human, and this geologic age which started approximately in the previous century, is called the Anthropocene because humans now have the greatest impact on the environment.

We are causing the climate crisis. Among our crisis-causing actions are:

1. Burning fossil fuels for energy, including for transportation and manufacturing. Fossil fuels release carbon dioxide (CO2), a greenhouse gas, into the atmosphere.

2. Cutting down forests to grow food and build roads and buildings. Trees soak up CO2; fewer trees means more $\mathrm{CO} 2$.

3. Using animals for food. Animals release the greenhouse gases methane and nitrous oxide. Also, animals are an inefficient food source, because they have to each eat many $\mathrm{kgs}$ of plants to produce just one $\mathrm{kg}$ of meat.

The climate crisis exacerbates other problems. Many of these problems are highlighted in the United Nations' Sustainable Development Goals [18], commonly known as the 17 SDGs. The SDGs were initiated in 2015, and the hope is to make significant progress toward their attainment by 2030 . The SDGs are shown in Figure 1. 

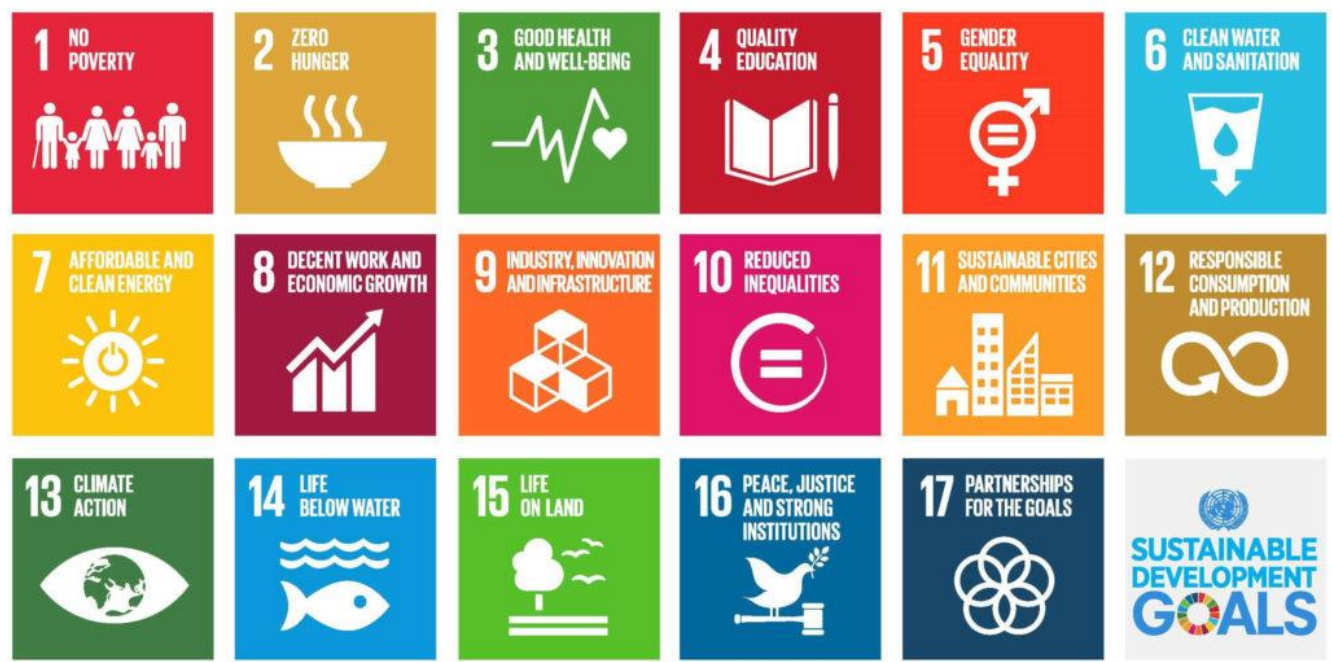

SUSTAINABLE DEVELOPMENT

Fig 1. - The United Nations Sustainable Development Goals

SDG 13 directly involves the climate crisis, but as stated previously, the climate crisis impacts all the goals. For instance, due to the climate crisis, droughts and flooding are more frequent, thereby lowering crop yields which worsens poverty, SDG 1, and increases hunger, SDG 2. At the same time, children suffering poverty and hunger have poorer health, SDG 3, and face difficulty attending school, SDG 4. Fortunately, just as people caused the climate crisis, so too can we solve it. This is discussed in Part 3.

\section{Part 3 - What Education Institutions, Teachers, and Students Can Do To Address The Climate Crisis}

Educators have begun to address the climate crisis. An outstanding example of these efforts is Maley and Peachy (2017) [9] a free online book of edited lesson plans, one for each of the 17 SDGs. The book begins with a poem by Maley who argued strongly for teachers to step beyond the confines of their syllabus to include the climate crisis and other vital issues and habits. Here is that poem. The lines in regular font are the voice of someone who believes teachers, in this case English teachers, should limit themselves to a narrow view of their role.

\section{A Poem}

\section{Teacher}

What do you do?

\section{I'm a teacher.}

What do you teach?

People. 
What do you teach them?

\section{English}

You mean grammar, verbs, nouns, pronunciation, conjugation, articles and particles, negatives and interrogatives ...?

\section{That too.}

What do you mean, 'that too'?

Well, I also try to teach them how to think, and feel - show them inspiration, aspiration, cooperation, participation, consolation, innovation

... help them think about globalization, exploitation, confrontation, incarceration, discrimination, degradation, subjugation,

...how inequality brings poverty, how intolerance brings violence,

how need is denied by greed,

how -isms become prisons,

how thinking and feeling can bring about healing.

Well I don't know about that. Maybe you should stick to language, forget about anguish. You can't change the world.

\section{But if I did that, I'd be a cheater, not a teacher.}

\section{THE END}

\section{UN Environment Program's Environmental Education Objectives}

The United Nations Environment Program's six objectives for environmental education (UNESCO-UNEP, 1976) can serve as a framework for student and teacher involvement in tackling the climate crisis. The six objectives are explained below.

1. Awareness of climate change involves knowing that climate change is taking place and what the effects of climate change might be. Students and teachers need to ask what is done now and what else can we do to raise people's awareness?

2. Understanding the whys and hows of climate change, including humans' role in climate change. What is done now and what else can we do to increase people's understanding?

3. Concern, i.e., do people care about others who may be more affected by a particular environmental issue? In the case of climate change, large pieces of land may soon disappear under the oceans if climate change proceeds to result in rising water levels. What is done now and what else can we do to heighten people's concern?

4. Skills, i.e., do students have the skills necessary to address environmental issues. Here, all languages play a key role, as well as the ability to critically listen, read, and view 
language produced by others. How could we help students develop and utilize skills to slow climate change?

5. The ability to evaluate different "green" proposals. Do they really protect the Earth, or are they just greenwashing? What is a green proposal that is genuine, not greenwashing?

6. The last, but maybe most important, UN objective advocates that teachers, students, and others involved in education, such as school canteen staff, go beyond thinking about the environment and actively participate in protecting it. What is done now and what else can be done to increase people's participation?

\section{Ideas for Participation in Slowing Climate Change}

What can students and teachers do to meaningfully participate (1897) in the worldwide movement against climate change? Below are some general suggestions regardless of where people live.

1. Convince governments, institutions, and corporations to change. While individual change is also useful, change on a larger scale has more power.

2. Reduce food from animals. As mentioned earlier, animal-based foods are one of the largest sources on human-produced greenhouse gases [10].

3. Use the relative pronoun 'who' with animals in order to treat our fellow animals as the thinking, feeling beings they are [11].

4. Support karung gunis, i.e., waste material collectors. These people may have low social status, but they should be honored as climate crisis warriors.

5. Similarly, we should buy second-hand goods.

6. Along the same lines, we should support green businesses. How to know if a business is green? This is where evaluation ability comes into play.

7. Even better that supporting existing green businesses is to create new ones.

8. On the academic front, we can organize and attend online conferences, webinars, etc. Online events are open to more people and create much less environmental damage. These events can be for younger students.

9. People who study and teach languages may wish to learn about ecolinguistics, the application of language sciences to better understand our interaction with the environment, e.g., http://ecolinguistics-association.org/

Two Indonesia Examples of Student-Centered Learning for Participation 
By giving students more power and by bringing the curriculum closer to students' lives, student-centered learning fits well with participation in addressing the climate crisis. As Maley noted in his poem, he tries to teach students "how to think, and feel - show them inspiration, aspiration, cooperation, participation, consolation, innovation." Lie et al. (2002) [12] is a collection of chapters written by teachers from various Indonesian universities explaining how they include participation in environment-friendly actions in their classes for non-English majors.

One of the chapters deal with supporting karung gunis. The ideas below come from the chapter with more ideas added.

1. Learn about second-hand goods and the circular economy, via reading, podcasts, and TED Talks.

2. Interview karung gunis and translate the interviews to English.

3. Use social media, etc. to convince people to help and thank karung gunis.

4. Write a bilingual Bahasa/English story book about karung gunis.

5. Create a dance and song about second-hand products.

6. Spend half a day accompanying a karung guni and journal about the experience.

Another way to support the SDGs, especially SDG 6, Clean Water and Sanitation, is an Indonesia-based project called Safe Water Gardens (SWGs): https://safewatergardens.org. Many homes in rural Indonesia and other third-world countries lack sanitation systems. SWGs not only safely dispose of human waste, they also use that waste to fertilize gardens. This not only saves children's lives, SWGs also boost families' income and reduce air pollution that worsen greenhouse gas emissions.

Local and overseas universities - UMRAH, Universitas Gadjah Mada, National University of Singapore, and Eindhoven University of Technology (Netherlands) have been involved in the planning and monitoring of the SWGs project. Furthermore, students in primary and secondary schools have built SWGs with their own hands as well as contributing funds. During the pandemic, these students have watched SWGs being built, learned from the families, and contributed ideas about which plants might be the most nutritious and profit-making to grow in the gardens. Figure 2 shows the key components of a Safe Water Garden, and Figure 3 shows a group of students celebrating the construction of a Safe Water Garden in a village in Bintan, Indonesia. 


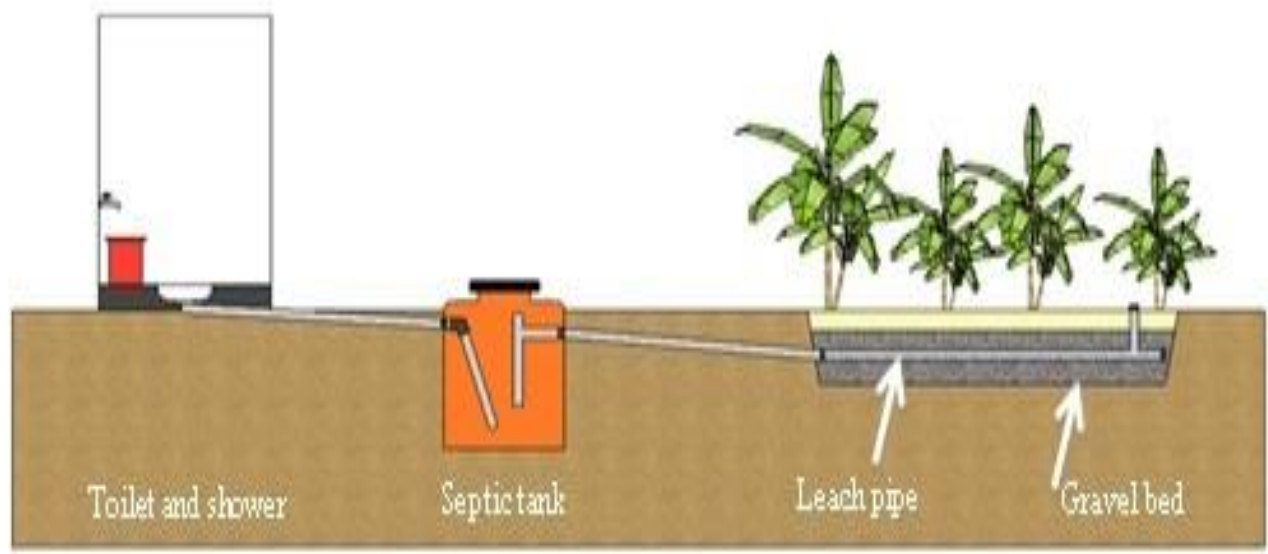

Fig 2. Key Components of a Safe Water Garden

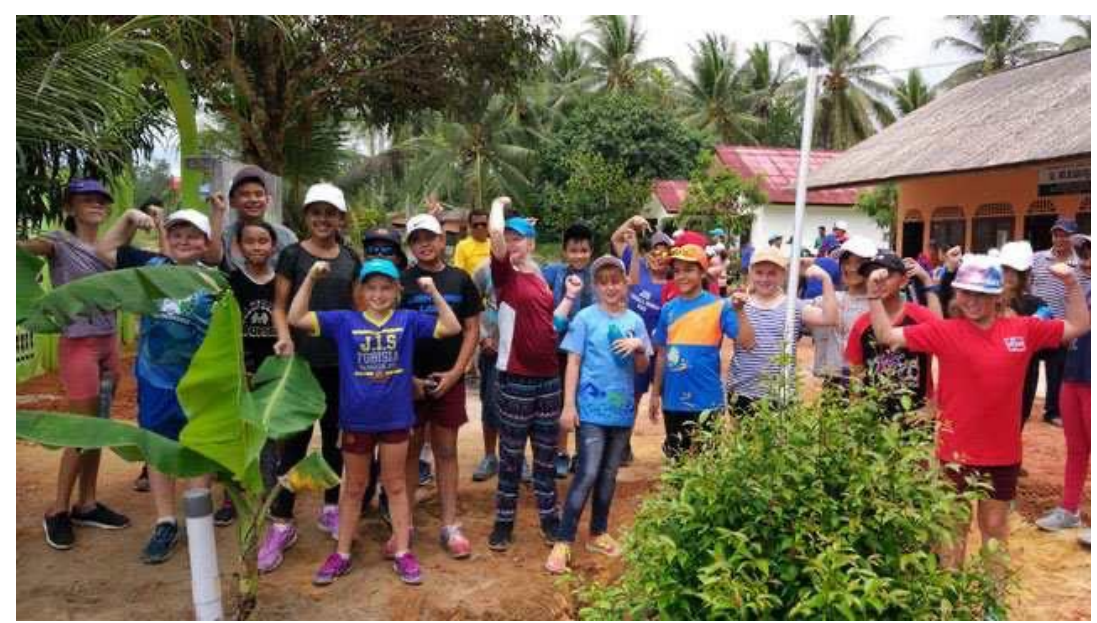

Fig 3. Students Celebrating After Building a Safe Water Garden in Bintan, Indonesia

\section{Conclusion}

To conclude, student-centered learning provides a way to unleash the power of students to protect the future of humans and other animals on this planet, as we attempt to slow and even reverse the climate crisis. Let us please remember the plea of this young person from a photo taken from the Internet. 


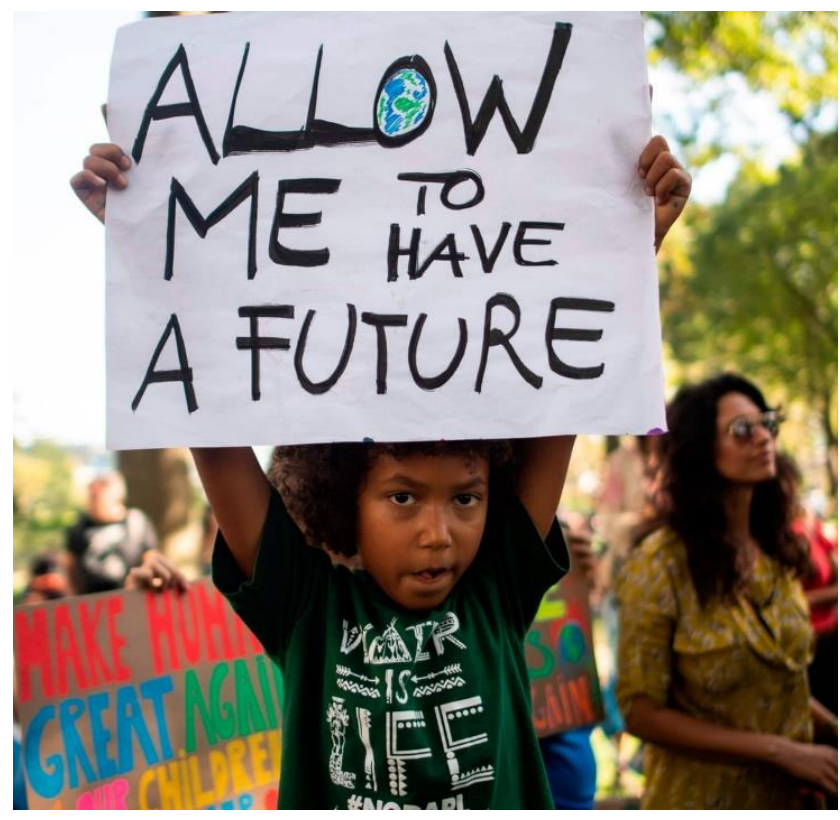

\section{References}

[1] Armstrong, T. (2017). Multiple intelligences in the classroom ( $4^{\text {th }}$ ed.). Association for Supervision and Curriculum Development.

[2] Attenborough, D. (2021). Speech at the 2021 United Nations Climate Change Conference, Glasgow, Scotland. https://www.youtube.com/watch?v=o7EpiXViSIQ

[3] Bloom, B. S., Engelhart, M. D., Furst, E. J., Hill, W. H., \& Krathwohl, D. R. (1956). Taxonomy of educational objectives. Vol. 1: Cognitive domain. McKay.

[4] Bruner, J. S. (1973). Beyond the information given: Studies in the psychology of knowing.

[5] Chau, M. H., \& Jacobs, G. M. (2021). Applied Linguistics, language guidelines, and inclusive practices: The case for the use of who with nonhuman animals. International Journal of Applied Linguistics, 31(2), 301-303. https://doi.org/10.1111/ijal.12357

[6] Dewey, D. (1897). My pedagogic creed”, School Journal, 54, 77-80.

[7] Extensive Reading Foundation. (n.d.). Guide to extensive reading. https://erfoundation.org/guide/ERF_Guide.pdf

[8] Faqiroh, B. Z. (2020). Problem based learning model for junior high school in Indonesia (2010-2019). Indonesian Journal of Curriculum and Educational Technology Studies, 8(1), 42-48.

[9] Goldberg, J. M., Sommers-Spijkerman, M. P., Clarke, A. M., Schreurs, K. M., \& Bohlmeijer, E. T. (2021). Positive education in daily teaching, the promotion of wellbeing, and engagement in a whole school approach: a clustered quasi-experimental trial. School Effectiveness and School Improvement, 1-20. 
[10] Good Food Institute. (2021). Cultivated meat. https://gfi.org/cultivated

[11] Jacobs, G. M., Renandya, W. A., \& Power, M. (2016). Simple, powerful strategies for student centered learning. Springer International Publishing.

[12] Johnson, D. W., \& Johnson, R. T. (2009). An educational psychology success story: Social Interdependence Theory and cooperative learning. Educational Researcher, 38(5), 365-379.

[13] Lancaster, R. W. (2017). A comparison of student-centered and teacher-centered learning approaches in one alternative learning classroom environment. [Doctoral dissertation, Arkansas State University.] ProQuest Dissertations Publishing.

[14] Lasfeto, D. (2020). The relationship between self-directed learning and students' social interaction in online learning environment. Journal of E-Learning and Knowledge Society, 16(2), 34-41.

[15] Lewis, S. L., \& Maslin, M. A. (2015). Defining the anthropocene. Nature, 519(7542), 171-180.

[16] Lie, A., Jacobs, G. M., \& Amy, S. (Eds.). (2002). English via environmental education. Grasindo.

[17] Maley, A., \& Peachy, N. (2017). Integrating global issues in the creative English language classroom: With reference to the United Nations Sustainable Development Goals. British Council. https://www.teachingenglish.org.uk/sites/teacheng/files/PUB_29200_Creativity_UN_SD G_v4S_WEB.pdf

[18] United Nations Development Program. (2020). Sustainable Development Goals. https://www.undp.org/content/undp/en/home/sustainable-developmentgoals/background.html.

[19] UNEP. (1976). The Belgrade Charter: A global framework for environmental education. Connect, 1(1): 1-9. 